\title{
Reproductive biology, diet and feeding pattern of longtail tuna Thunnus tonggol (Bleeker, 1851) in the north-eastern Arabian Sea off Gujarat, India
}

\author{
K. MOHAMMED KOYA ${ }^{1}$, PRATHIBHA ROHIT ${ }^{2}$, E. M. ABDUSSAMAD ${ }^{1}$, P. ABDUL AZEEZ ${ }^{3}$, \\ VINAY KUMAR VASE ${ }^{3}$ AND A. SANGITA BHARADIYA ${ }^{3}$ \\ ${ }^{1}$ ICAR-Central Marine Fisheries Research Institute, Ernakulam North P. O., Kochi - 682018 , Kerala, India \\ ${ }^{2}$ ICAR-Central Marine Fisheries Research Institute, Mangalore Research Centre, Hoige Bazar, Mangaluru - 575001 \\ Karnataka, India \\ ${ }^{3}$ ICAR-Central Marine Fisheries Research Institute, Veraval Regional Centre, Bhidiya Plot, Veraval - 362269 \\ Gujarat, India \\ e-mail: koya313@gmail.com
}

\begin{abstract}
Longtail tuna Thunnus tonggol (Bleeker, 1851) is the major tuna resource in the neritic realms of the northern Arabian Sea and forms considerable fishery in the coastal nations in the region. Gujarat, on the north-west coast is the major province landing longtail tuna in India. The paper attempts to add to the hitherto sparse knowledge base on biology of the longtail tuna fished along the north-west coast of India, through a study spanning from 2011 to 2015. Reproductive biology, spawning, food and feeding dynamisms of the species were investigated. Sex ratio of the species was estimated as 1:2.1 and depicted an increase in male preponderance as the size increased. The fish attains maturity at $607 \mathrm{~mm}$ and it spawns during summer months starting from May. The fish is typically a non-selective feeder and over 22 taxa comprising of fishes, cephalopods and crustaceans formed the diet at varying rates over the year. Variation in feeding intensity at different reproductive stages is discussed besides the constraint posed by the large presence of unidentifiable, partially digested gut content.
\end{abstract}

Keywords: Diet, Longtail tuna, Northern Arabian Sea, North-west coast of India, Reproduction

\section{Introduction}

The longtail tuna Thunnus tonggol (Bleeker, 1851), is a neritic tuna species distributed in the Indo-West Pacific from Japan coast through the Philippines to Papua New Guinea to the coast of Australia, East Indies, India, Arabian Peninsula, the Red Sea and the Somalia Coast (Collette and Nauen, 1983). Globally, the Northern Arabian Sea is considered to be the major area of abundance for long tail tuna and there exist a good fishery in Oman, Iran, Pakistan and North-West India. Gujarat, with coastline of over $1,600 \mathrm{~km}$ is a major coastal state bordering the north-eastern Arabian Sea along the north-west coast of India. T. tonggol is the most important tuna species in Gujarat forming $50 \%$ of the total tuna landings and Gujarat contributed almost $75 \%$ of the longtail tuna landings in India (Abdussamad et al., 2012).

Information on the reproductive biology of this species in the north-eastern Arabia Sea is limited to the studies by Hidayatifard (2007), Kaymaran et al. (2011) and Abdussamad et al. (2012). Abdussamad et al. (2012) provided a pan India account of the fishery and biology of longtail tuna with data collected during 2006 to 2010 with limited emphasis on the fishery of the north-west coast where the longtail tuna enjoys considerable fishery.
Longtail tunas are opportunistic coastal epipelagic predators that mainly feed on small pelagic fishes, cephalopods and crustaceans. Quantitative account of feeding ecology of the longtail tuna is scanty from the north-east Arabain Sea. The available information on the diet of the species is limited to those by Serventy (1942, 1956) and Griffith et al. (2007) from Australia; Silas (1967) from the south-east coast of India; Wilson (1981) from Gulf of Papua and Abdussamad et al. (2012) from India.

The focus of the present paper therefore was to gather in-depth information on the reproductive biology and trophodynamics of longtail tuna exploited along the north-west of India.

\section{Materials and methods}

Sample collection and processing

The study covered samples drawn from the longtail tuna exploited off Gujarat by large-mesh multi-day gillnetters based at Veraval, Mangrol and Vanakbara fishing harbours during January 2011 to December 2015. In all, 373 numbers of longtail tunas were collected and analysed. Fishing is prohibited during the south-west monsoon months (June to August) by the statutory and customary 
laws of Gujarat State and hence sampling during the years of study was limited to fishing months. Samples collected from the landing centres were iced and transported to the laboratory and kept frozen till further analysis. The lengths $(0.01 \mathrm{~mm})$ and weights $(0.01 \mathrm{~g})$ of the fishes sampled were recorded and then individual fishes were dissected for detailed studies on reproductive and feeding biology.

The sex and gonad maturity stages were noted following Yesaki (1987) (5 point scale); based on the size of gonad, colour, degree of softness and turgidity. Stage IV was considered as mature and $\mathrm{V}$ as spent. The gonads were then carefully removed, trimmed of fat and weighed $(0.001 \mathrm{~g})$. The Gonadosomatic index was calculated using the equation of Kume and Joseph (1969):

$$
\text { GSI }=\frac{\text { Gonad weight }(\mathrm{g})}{\text { Total body weight }(\mathrm{g})-\text { Weight of } \operatorname{gonad}(\mathrm{g})} \times 100
$$

Fecundity and ova diameter studies were limited to mature specimens. During the entire period of study, only one specimen in advanced stage of maturity was found. The month-wise data on distribution of males and females were pooled and subjected to $C h i$-square test to ascertain homogeneity of male and female distribution in the population. The length at first maturity $\left(\mathrm{L}_{\mathrm{m}}\right)$ was determined using logistic curve by considering fishes with ovaries at stages IV and above. Monthly spawning percentage [(No. of fishes matured/Total no. of fishes observed)*100] was estimated by considering gonads only in advanced stages of maturity (IV and V).

Quantitative and qualitative studies on the diet of longtail tuna was done following the method used by Khanna and Singh (2005). The length as well as wet weight of whole stomach was recorded. It was then carefully cut open and prey items sorted and identified to the nearest taxonomic level possible. Each group of the food items thus identified was counted and weighed $(\mathrm{g})$. The relative importance of various food items in the stomach was determined by estimating Index of Relative Importance (IRI) (Pinkas et al., 1971) which was computed as:

$$
\mathrm{IRI}=(\% \mathrm{~N}+\% \mathrm{~V}) \times \mathrm{x}
$$

where, $\mathrm{N}=$ number, $\mathrm{V}=$ volume and $\mathrm{F}=$ frequency of occurrence.

PAST3 and R software were used to compute non-metric multidimensional scaling (nMDS) to examine monthly differences in diet and similarity percentages (SIMPER) to determine the prey dissimilarity between months.

The feeding status was assessed based on the distension of the stomach and the volume of food contained in it. The stomach distension was classified as full, $3 / 4$ full, $1 / 2$ full, $1 / 4$ full and empty. Feeding periodicity was determined by analysing the feeding intensity. Stomach fullness index (SFI) was used to measure the degree of feeding intensity (Chiou et al., 2006). SFI was calculated as: SFI = [weight of the stomach contents/(body weight - weight of the stomach contents) $] \times 100$.

\section{Results and discussion}

\section{Distribution ratio of males to females}

Sexes in $T$. tonggol were separate with no distinguishing external features. Analysis of the monthly sex ratio of males and females revealed that the overall sex ratio was 1:2.1 with a preponderance of females throughout the year except in May. Chi-square test also indicated significant $(p<0.5)$ dominance of females in January, March, April, September, November and December (Table 1). Similarly, females dominated in all the length groups except in $75-80 \mathrm{~cm}$ length range (Fig. 1). Percentage of males in different length classes exhibited a significant increasing trend with increase in fish length and vice versa (Fig. 2 and 3).

Table 1 . Monthly variations in the sex ratio of T. tonggol

\begin{tabular}{lllllll}
\hline \multirow{2}{*}{ Month } & \multicolumn{3}{c}{ No. of individuals } & \multicolumn{2}{l}{$\begin{array}{l}\text { Sex ratio } \\
\text { nale }\end{array}$} & \multicolumn{2}{l}{ Female } & Total & $\begin{array}{l}\text { Chuare } \\
\text { value }\end{array}$ & p value \\
& & & & & \\
January & 16 & 32 & 48 & $1: 2^{*}$ & 5.3333 & 0.0209 \\
February & 14 & 20 & 34 & $1: 1.43$ & 1.0588 & 0.3035 \\
March & 7 & 20 & 27 & $1: 2.86^{*}$ & 6.2593 & 0.0124 \\
April & 5 & 18 & 23 & $1: 3.6^{*}$ & 7.3478 & 0.0067 \\
May & 7 & 2 & 9 & $1: 0.29$ & 2.7778 & 0.0956 \\
June & 2 & 6 & 8 & $1: 3$ & 2.0000 & 0.1573 \\
August & 11 & 21 & 32 & $1: 1.91$ & 3.1250 & 0.0771 \\
September & 15 & 35 & 50 & $1: 2.33^{*}$ & 8.0000 & 0.0047 \\
October & 11 & 19 & 30 & $1: 1.73$ & 2.1333 & 0.1441 \\
November & 23 & 47 & 70 & $1: 2.04^{*}$ & 8.2286 & 0.0041 \\
December & 8 & 31 & 39 & $1: 3.88^{*}$ & 13.5640 & 0.0002 \\
Annual & 119 & 251 & 370 & $1: 2.11$ & & \\
\end{tabular}

*Female number in the population significantly higher $(\mathrm{p}<0.05)$

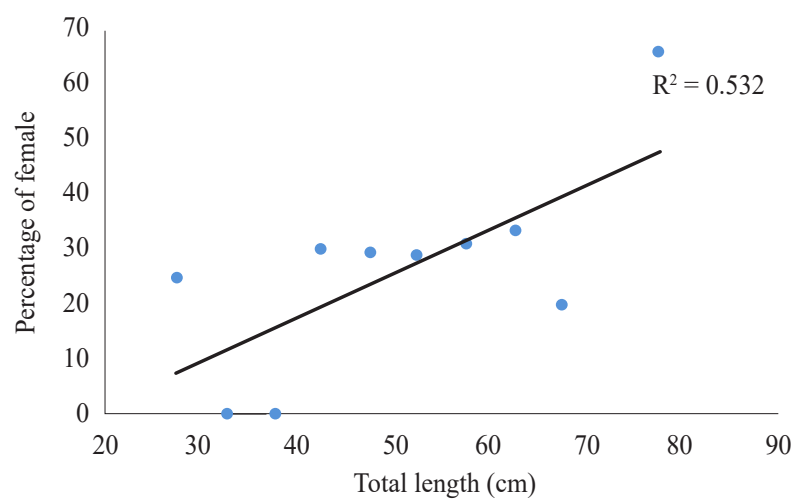

Fig. 1. Percentage of males in different length classes of $T$. tonggol 


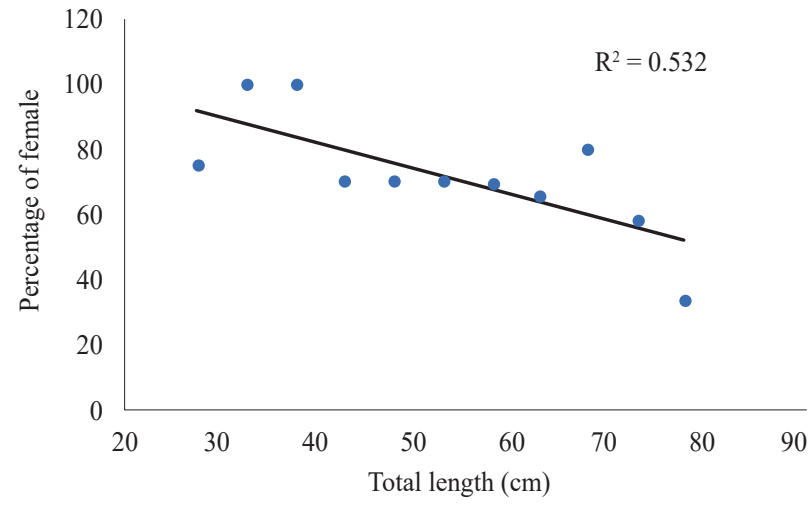

Fig. 2. Percentage of females in different length classes of $T$. tonggol

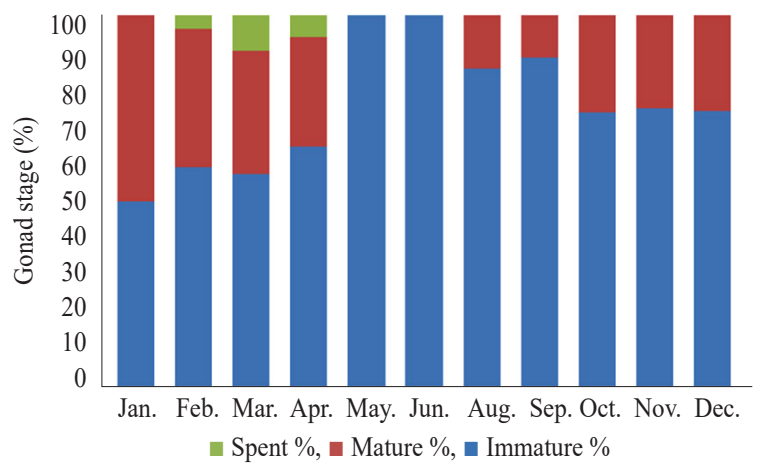

Fig. 3. Monthly distribution (\%) of maturity stages in T. tonggol ovaries

\section{Length at maturity}

Fifty percent of the individuals of $T$. tonggol in the population attained sexual maturity at total length of $607 \mathrm{~mm}$ (Fig. 4) and the individuals of this size were observed in all the months except May and June. Twenty five percent of fish matured when they attained $552 \mathrm{~mm}$ while $75 \%$ at $666 \mathrm{~mm}$ total length (Fig. 4).

\section{Gonadosomatic index (GSI)}

Monthly GSI values increased from December and reached its peak in April. Thereafter, the GSI values dropped

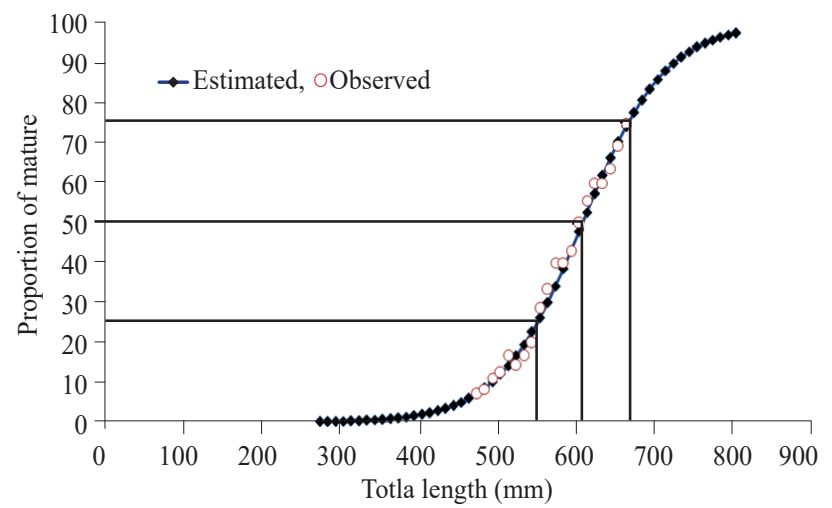

Fig. 4. Percentage of mature T. tonggol specimens showing lengths at 25,50 and $75 \%$ maturity rapidly and lowest value was observed during May (Fig. 5). This suggests that the ovaries were maturing continuously from December till April. Smaller peaks of GSI values were also observed during August and November (Fig. 5).

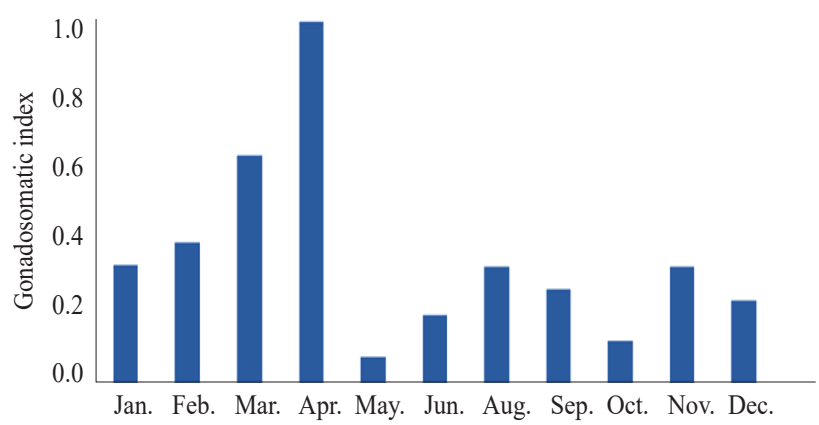

Fig. 5. Monthly variations in mean GSI of $T$. tonggol

\section{Food and feeding}

Prey preference and diversity

A total of 362 stomachs of $T$. tonggol ranging in size from 25.8 to $85 \mathrm{~cm}$ fork length (FL) were examined. Of the 362 stomachs examined, $68 \%$ were empty. The diet comprised 22 diverse groups/taxa, mainly fishes (52\%), crustaceans (26\%) and cephalopods (4\%) along with partially digested food items (10\%) (Fig. 7). A considerable quantity $(8 \%)$ of plastic materials $(8 \%)$ was also observed in the gut content. The major fish groups present in the diet included Stolephorus spp., Rastrelliger kanagurta, Platycephalus sp., Trichiurus lepturus, Sardinella sp., Auxis thazard, Megalaspis cordyla, sciaenids and clupeids. Crustaceans included Solenocera sp., Squilla sp., partially digested unidentified deep sea shrimps and other shrimps. Squid, cuttlefish and octopus were the three groups of cephalopods present in the stomach. A few prey items found in the stomach could not be identified, as they were in advanced stages of digestion with only skeletal remains (Fig. 6). Gut contents indicated absence of cannibalistic nature for the species.

The IRI was considered as it takes into account the frequency of occurrence as well as the number and

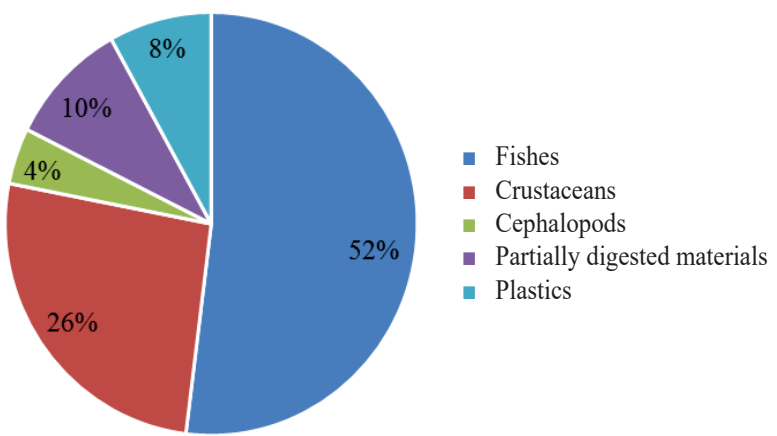

Fig. 6. Major prey groups constituting the diet of T. tonggol 
volume of each food item, which provides a definite and measurable basis for grading different food items. The relative importance of different food items ingested by T. tonggol during different months (2011-15) is given in Table 2.

\section{Seasonal variations in the feeding pattern}

The number of prey taxa consumed differed markedly among months, with fish having the most diverse diet recorded during April and September (12 and 9 taxa) and the least diverse diet in October (2 taxa). With respect to diet composition, multidimensional scaling (MDS) ordinations showed a similar grouping of taxa in months with close proximity of samples in the months of March, April and December, whereas January, February, October and November samples were far away from each other (Fig. 7). SIMPER analysis revealed a high dissimilarity (68.56\%) in diets among months. Out of the 22 taxa/groups found in gut content of $T$. tonggol, partially digested materials was observed during all months (9 months), partially digested unidentified fish and Loligo sp. during 7 months, T. lepturus during 6 months and unidentified partially digested shrimps during 5 months.

\section{Feeding intensity}

Details of analysis of the ontogenetic variation of stomach status is depicted in Fig. 8. Most of the

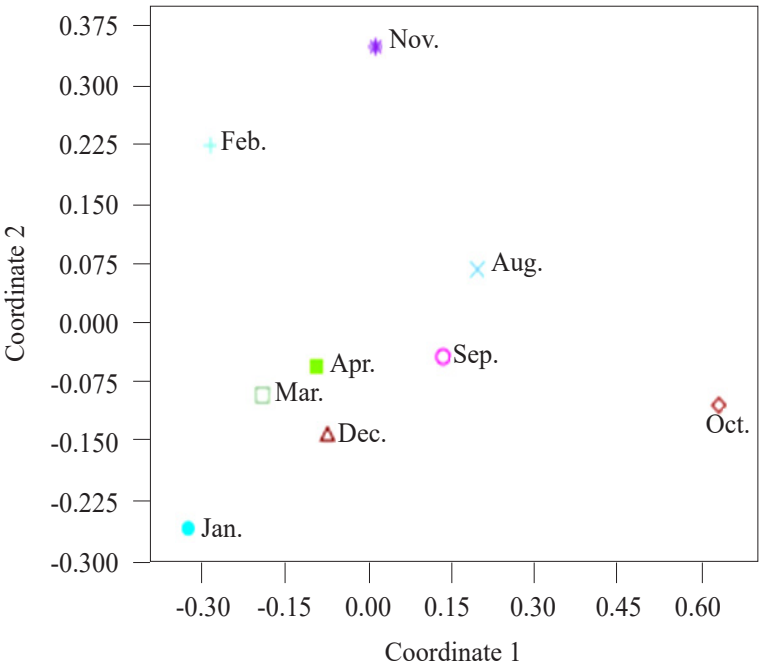

Fig. 7. MDS ordination of diet data for T. tonggol caught in different months

examined specimens were with empty stomachs. The least proportion of empty stomachs (33.33\%) was observed in fishes in the 75-80 cm FL group. Empty stomachs were more prevalent in smaller sized fishes with the highest proportion of empty stomachs (100\%) in 30-35 cm FL group. The percentage of longtail tunas with three fourth stomach contents was also very low (Fig. 8).

Table 2. Monthly IRI values of different dietary components of $T$. tonggol during 2011-15

\begin{tabular}{|c|c|c|c|c|c|c|c|c|c|c|}
\hline Prey groups & Jan. & Feb. & Mar. & Apr. & Aug. & Sep. & Oct. & Nov. & Dec. & Average \\
\hline Partially digested unidentified fish & 52.10 & 16.88 & 46.23 & 31.14 & & 12.29 & & 3.03 & 38.89 & 28.65 \\
\hline Stolephorus sp. & - & 34.04 & - & - & - & - & - & - & - & 34.04 \\
\hline Unidentified deep sea shrimps & - & - & - & 18.43 & - & - & - & - & - & 18.43 \\
\hline Octopus sp. & - & - & - & 0.50 & - & - & - & - & - & 0.50 \\
\hline Partially digested (semisolid) material & 1.49 & 2.19 & 13.44 & 19.99 & 34.84 & 30.45 & 83.70 & 22.45 & 29.60 & 26.46 \\
\hline Solenocera sp. & - & - & - & 1.67 & - & - & 16.30 & - & - & 8.98 \\
\hline Unidentified cephalopods & - & - & - & 3.71 & - & - & - & - & - & 3.71 \\
\hline Platycephalus sp. & - & - & - & 0.71 & - & - & - & - & - & 0.71 \\
\hline Sardinella sp. & - & - & - & 0.61 & - & - & - & - & - & 0.61 \\
\hline Trichiurus lepturus & 13.73 & 8.90 & - & 9.95 & 18.86 & 2.19 & - & - & 6.48 & 10.02 \\
\hline Scoliodon sp. & - & - & - & 1.11 & - & - & - & - & - & 1.11 \\
\hline Squilla sp. & - & - & - & - & - & 30.86 & - & - & - & 30.86 \\
\hline Sciaenids & - & 2.02 & 15.04 & - & - & 10.99 & - & 2.06 & - & 7.53 \\
\hline Acetes sp. & 1.68 & - & - & - & 9.06 & 2.67 & - & 0.65 & - & 3.51 \\
\hline Partially digested unidentified crustaceans & - & - & - & - & - & 1.47 & - & - & - & 1.47 \\
\hline Uroteuthis (P.) sp. & 1.73 & 2.72 & 11.33 & 1.33 & 24.38 & 6.04 & - & 6.07 & - & 7.66 \\
\hline Rastrelliger kanagurta & - & - & - & - & - & - & - & 24.61 & - & 24.61 \\
\hline Plastic materials & - & - & - & - & - & - & - & - & 22.30 & 22.30 \\
\hline Partially digested unidentified shrimps & 29.27 & 4.37 & 4.67 & 10.85 & 3.49 & - & - & - & 2.73 & 8.91 \\
\hline Megalaspis cordyla & - & - & - & - & - & - & - & 2.59 & - & 6.72 \\
\hline Clupeids & - & - & 2.22 & - & 9.37 & 3.05 & - & - & - & 4.88 \\
\hline Auxis thazard & - & 28.89 & 7.06 & - & - & - & - & 38.55 & - & 24.83 \\
\hline
\end{tabular}




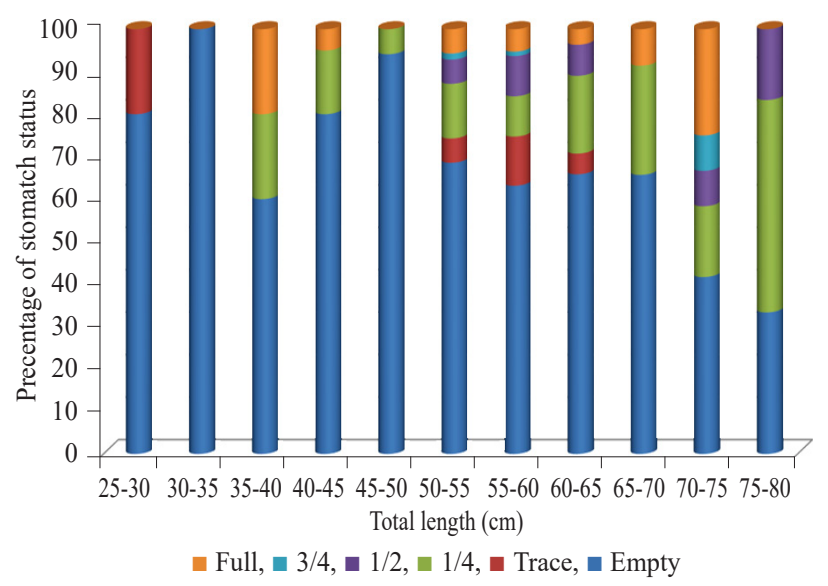

Fig. 8. Variations in the stomach status in different length classes of T tonggol

Monthly analysis of percentage of empty stomachs revealed highest $(100 \%)$ in May and June and lowest (41.67\%) in December (Fig. 9). Stomach with three fourth contents was low in all the months and full-stomachs were observed in higher numbers in post-monsoon months (August and September).

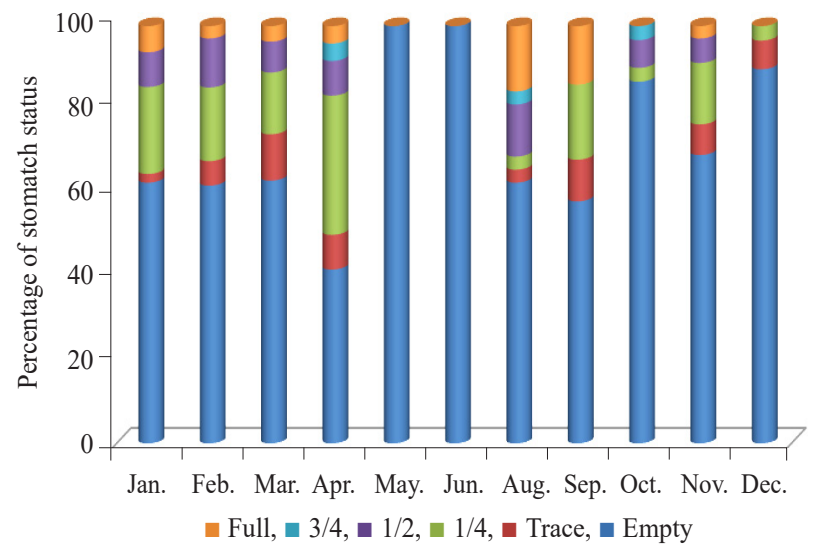

Fig. 9. Monthly variations in feeding intensity of $T$. tonggol

The mean stomach fullness index (SFI) were higher for females (Fig. 10) in all the length groups, except in $41-50 \mathrm{~cm}$ range whereas results of $t$ test analysis showed that SFI values between sexes for each size category of fish were not significantly different $(p>0.5)$. As size of the fish increased, the SFI increased in female. The lowest SFI value for females was observed in 41-50 FL group (1.39 \pm 0.63$)$ and the highest in 71-80 FL group (1.80 \pm 0.87$)$.

Monthly change in the feeding intensity in terms of SFI is shown in Fig. 11. The SFI varied considerably among months and the values were lower during May $(1.04 \pm 0.19)$ and October (1.04 \pm 0.17$)$ and higher during March (2.88 \pm 1.59$)$ and August (2.02 \pm 1.59$)$. After every

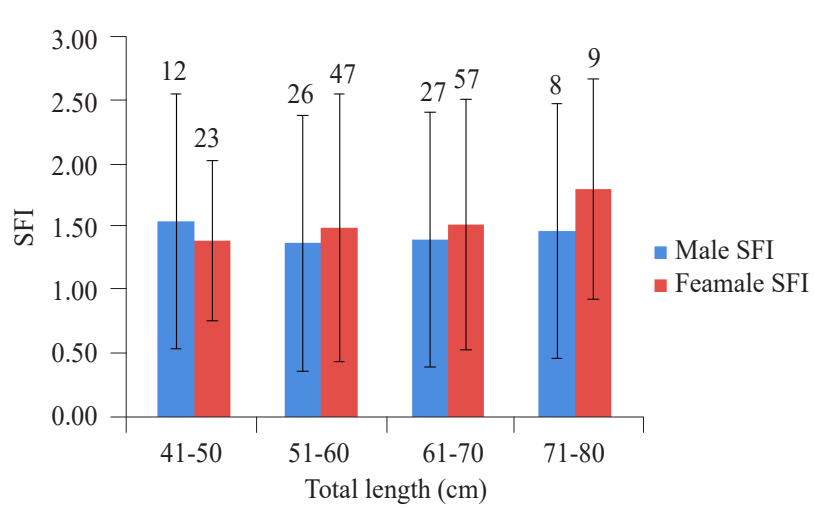

Fig. 10. SFI for different size classes of T. tonggol (vertical bars indicate standard deviation. No. of specimens examined is given above each bar)

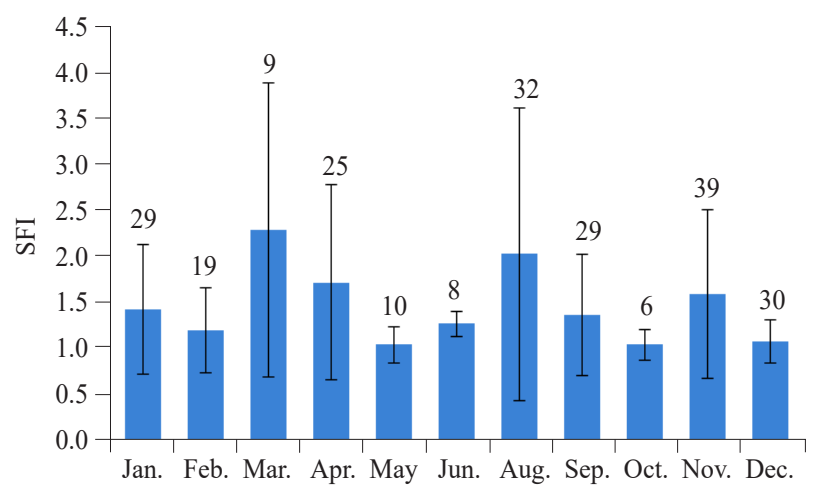

Fig. 11. Monthly variation of SFI of T. tonggol (vertical bars indicate standard deviation. No. of specimens examined is given above each bar)

peak, the SFI values declined gradually to the lowest values. This pattern in SFI showed a direct relationship with the reproductive activity with stomach fullness being highest in the months of highest reproductive activity and vice versa (Fig. 12). Statistically significant positive relationship was observed between GSI and SFI $\left(\mathrm{R}^{2}=0.39, \mathrm{p}=0.041042\right)$ (Fig. 13).

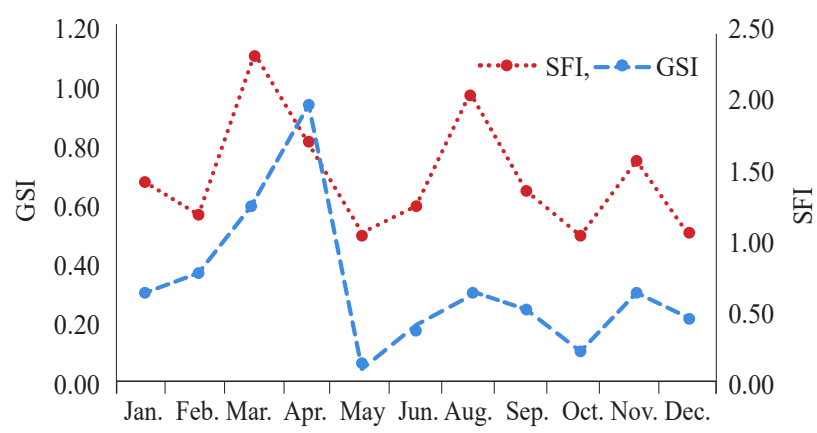

Fig. 12. Monthly mean SFI and GSI showing the relationship between feeding intensity and reproductive activity of T. tonggol 


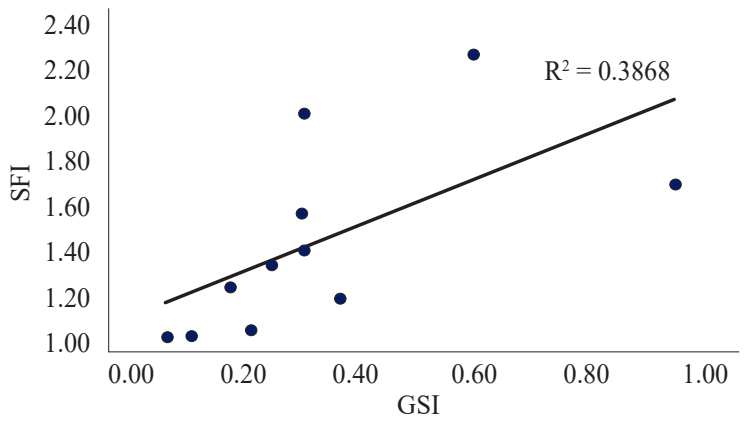

Fig. 13. Plot showing the relationship between reproductive activity (GSI) and feeding intensity (SFI) for T. tonggol

\section{Discussion}

Longtail tuna is a gonochoristic species with no evidence of sexual dimorphism (Griffiths et al., 2010). The overall male:female ratio of 1:2.1 observed in the present study depicted considerably higher preponderance of females in the fishery. Further, the proportion of males in the fishery increased significantly $\left(\mathrm{R}^{2}=0.53 ; \mathrm{p}<0.05\right)$ in the larger size classes (Fig. 2 and 3). Most of the earlier studies on the species world over have not reported such gross deviation in the male:female ratio from the normal ratio of 1:1 (Klinmuang, 1978; Wilson, 1981; Griffiths et al., 2010). There isn't any information on the sex ratio of the species in the Arabian Sea region for a comparison of the results. Griffiths et al. (2010) indicated a (2:1) bias towards males for fishes above $100 \mathrm{~cm}$ along the east coast of Australia. Increasing trend of males in the larger size classes has been noticed for several Thunnus species (Sudarshan et al., 1991; John and Sudarshan, 1993; Wild et al., 1995; Schaefer, 1998; Farley et al., 2003; Rohit and Rammohan, 2009). The largest longtail tuna specimen observed during the study was of $85 \mathrm{~cm}$ total length and probably if the representation of larger fishes above $100 \mathrm{~cm}$ in the sample was adequate, the sex ratio would have moved closer to 1:1. The exact reason of such uneven distributions of sex is yet to be determined (IPTP, 1992). Changes in sex ratio by fish length may be directly related with differences in growth rate and/or natural and fishing mortalities by sex (Fonteneau, 2002). The differences in sex ratios could also be due to differential fishing resulting from differences in migration pattern of males and females to and from the fishing grounds. However, further investigations are needed to understand the actual pattern of the spawning migration with regard to the spatial and temporal aspects and its effect on the fishery.

Mature gonads were observed throughout the year except in May and June (Fig. 5) with a major peak and minor peak in spawning during February-April and October respectively. Abdussamad et al. (2012) reported that the longtail tuna mature and spawn round the year with two peaks in spawning; during August-December and April-May. Other studies by Yesaki (1982), Cheunpan (1984) and Hedayatifard (2007) opined that peak season of spawning differed with geographical area and the exact factor is yet to be found. The results of the present study corroborated with the common trend suggested by most that spawning occurred over a period of several months during the warmest period of the year in a particular region, i.e., at the beginning and end of the monsoonal period. As in the case of earlier studies from different regions of the world, fully mature or ripe specimens (female or male) were not observed throughout the study period. Fishes with spent gonads too were rare, indicating a probable migration of fishes to outer neritic areas for spawning. These indicate certain degree of segregation of spawning population from rest of the stock. Based on their observations, Yesaki (1982) and Itoh et al. (1999) proposed outer neritic zone as the possible spawning ground of the species. Another study (unpublished) by the author on the spatio-temporal distribution of the longtail tunas revealed that gillnet-tuna fishing in Gujarat extended beyond $200 \mathrm{~m}$ depth zones in the outer neritic areas of the EEZ during summer months and the highest catch rate for larger fishes during the season were obtained from farther areas of the EEZ beyond $200 \mathrm{~m}$ depth zones. Incidence of a large longtail tuna $(145.2 \mathrm{~cm})$ in the Oman Sea off Salalah in longline operation (Davood et al., 2014) indicates availability of large longtail tunas in the deeper areas of northern Arabia Sea. It also indicates that the spawning population of the longtail tuna are safe from being caught by the existing fishing gears. Therefore, it is expected that a concerted joint study by the countries in the region with onboard sampling in deeper areas of the northern Arabian Sea using multiple gears will reveal more about the spawning grounds of the longtail tuna.

Present study revealed that $50 \%$ of the individuals of T. tonggol in the population attained sexual maturity as their body measured a total length of $60.7 \mathrm{~cm}$. There seems to be a large difference between the length at first maturity of females between the regions reported so far. T. tonggol is reported to attain sexual maturity at $39.6 \mathrm{~cm}$ in the Persian Gulf and Oman Sea (Hedayatifard, 2007) and at $37 \mathrm{~cm}$ in Taiwan waters (Chiang et al., 2011). Yesaki (1982) and Cheunpan (1984) from Thailand recorded 43 and $40 \mathrm{~cm}$ respectively as the length at maturity whereas, in the waters of Australia and Papua New Guinea, by macroscopic inspection of gonads, Wilson (1981) found that fish first matured at 51 and $60 \mathrm{~cm}$ in each respective region. Pillai and Ganga (1985) and Abdussamad et al. (2012) reported the length at first maturity $\left(\mathrm{LM}_{50}\right)$ as 51.1 and $50 \mathrm{~cm}$ respectively. 
The earlier studies from Indian waters used pooled dataset for the entire region spread along the east and west coasts of India with emphasis on the south-west coast and the present study focussed on the north-west coast alone, where the fishery is considerably larger and comprised of larger sizes as compared to rest of India. The difference observed in the length at first maturity of longtail tuna reported from different regions could be attributed to the changes in temperature of water resulting in changes in habitat preferences, eventually leading to shifts in the distribution patterns of the species (Helser and Almeida, 1997). Studies have revealed that many ectotherms mature younger and smaller in warmer environments, though they grow faster (Bror Jonsson et al., 2012; Aidan Hunter et al., 2015). Arabian Sea along the west coast of India, does undergo marked temperature cycles associated with the south-west monsoon (Sheppard et al., 1992) and these temperature fluctuations may partially explain the larger size at which fishes attain maturity (Al-Nahdi et al., 2009). The results obtained in the present study was expected to be closer to the size at maturity reported in Oman Sea and Persian Gulf off Iran by Hidayatifard (2007). However, the values reported in the said study could not be relied as it is much smaller than that from other regions and the methodology followed is not specified for a comparison.

The GSI is used as a measure of maturation in fishes (June, 1953). The highest GSI values in both sexes are due to increased weight of gonad at those stages (Shinkafi and Ipinjolu, 2012) and also due to the physiological and hormonal effects on the gonadal development of the fish (Bandpei et al., 2011). Few studies on longtail tuna have investigated the timing of spawning primarily using GSI in different areas. Most of these studies have reported that the spawning occurs over a period of several months during the warmest period of the year in a particular region (Wilson, 1981; Griffiths et al., 2007; Abdussamad et al., 2012). They also found that longtail tuna had a protracted reproductive period with few major and minor peaks of spawning. The present study has also depicted a major peak in March-April and two minor peaks during August and November. The aforesaid seasons were matching with peak spawning percentages of the species as well. Therefore, it can be deduced that major spawning occurs during the months of May-June and the mature fishes move to the deeper waters in the oceanic realm.

Knowledge on the biological aspects and the predator-prey interactions of longtail tuna is still limited along Indian coast. Very few studies have investigated the diet of longtail tuna, categorising it to be an opportunistic coastal epipelagic predator that mainly prey on small pelagic shoaling fishes, crustaceans and cephalopods (Wilson, 1981; Yesaki, 1987; Griffiths et al., 2007;
Abdussamad et al., 2012). Our results indicated that there is considerable variation in the gut content of the longtail tuna over months and ratifies the widely acclaimed view of the longtail tuna to be an opportunistic feeder and has not exhibited strong preference for any prey at species level. The diet principally comprised of smaller pelagic shoaling fishes, shrimps and cephalopods that occupy the column waters and few fishes like the sciaenids and crustaceans like squilla and Solenocera sp. which are bottom dwelling. Though the tunas are considered to be foraging more on the pelagic shoaling fishes, the presence of demersal resources in the longtail tuna diet, as observed in the present study as well as in few other studies indicates that this species has a more widespread food choices unlike many other large tuna species. This is probably due to the preference of longtail tuna for shallow neritic waters where they target slow-moving demersal resources at times when their preferred food is unavailable (Griffith et al., 2007).

Studies on the prey preference and diversity of longtail tunas in the region for comparison are limited. Studies on food and feeding habits of the species done elsewhere have shown that the coastal tunas feed on available neritic and epipelagic prey (Olson and Boggs, 1986). The dominant food of longtail tuna as per Abdussamad et al. (2012) comprised of smaller, pelagic shoaling fishes. The study from the Australian waters by Griffiths et al. (2007) also showed that the diet composed of small pelagic fishes (Engraulidae, Clupeidae, Scombridae, Belonidae and Hemiramphidae), demersal fishes (Carangidae, Leiognathidae and Sillaginidae), cephalopods (Teuthoidea and Sepia spp.) and crustaceans (Portunidae, Penaeidae and Squillidae). The results of earlier studies are complementary with that of the present study. Diversity and composition of diet varied markedly between months with dissimilarity to the tune of $68.56 \%$. Highest diversity in diet composition was observed in April and September (12 and 9 taxa) and the least in October (2 taxa) indicating highly opportunistic feeding habit for the species. Previous studies in the seas off Australia by Blaber (2002) and Griffiths et al. (2007) too have described the variations in diet diversity of the longtail tuna over space and time. Plastic debris floating on the sea surface tended to aggregate smaller fishes around it and the tunas accidently ingest these plastic materials while feeding on these associated fishes. Occurrence of plastic from land based sources are reported to be increasing in the coastal areas (Ogunola and Palanisami, 2016) and hence there is an increased risk of ingestion of plastic by fishes living in the neritic realm.

One of the major constraints of the present study that limited the interpretations of the results of diet diversity and prey preference of the longtail tuna at different ontogenetic stages or seasons is the presence of unidentifiable partially 
digested gut contents. Such large presence of unidentifiable partially digested components in tuna guts is attributed to its innate habit of feeding during the day time as they are visual predators (Nakamura, 1968). Roger (1994) found that all the guts of tunas sampled from sets under fish aggregating devices (FADs) before sunrise were empty. The soft bodied prey like shrimps, cephalopods and soft skinned fishes in the gut get digested by the time they are caught in the gillnet which are mostly operated during night (Griffith et al., 2007). The gillnetters operating along the north-west coast of India undertake fishing trips lasting for 5-7 days with their catch preserved in ice. During this period, the gut contents are further digested due to enzymatic and bacterial degradation. Sivadas and Wesley (2007) observed that the gut contents of the tunas caught during daytime were intact and nearly fresh which indicate that integration of sampling from day fishing operations like troll line would reveal more details on the diet of longtail tuna.

Fishes with empty stomach condition predominated during the present study period. The presence of high percentage of empty stomachs is characteristic of piscivorous fishes (Faltas, 1993; Juanes and Conover, 1994). Tunas rely heavily on their high visual acuity to capture prey (Nakamura, 1968), which probably also explains why we found longtail tuna with a large proportion of guts with empty stomach as they were caught from night fishing operations. The stomach fullness varied with time/ season as well as size of the fish. Ontogenetic shifts in diet are widespread among fish which are a function of an increase in the sizes of body and mouth; permitting the individuals to capture preys of broader size ranges and types (Labropoulou et al., 1997). However, significant relationship was observed between fish size and the size of prey consumed by longtail tuna (Griffiths et al., 2007).

Feeding intensity in terms of SFI varied considerably between different sizes as well as months with peaks in March and August which are established to be the pre-spawning months. The fish require more energy during spawning than other phases. Studies have pointed out that the highest nutritional demand of the ribbonfishes (T. lepturus) is during its reproductive activity (Martins et al., 2005; Chiou et al., 2006). Higher SFI values in March-April, the months prior to major spawning period and increased number of empty stomachs during May-June, the major spawning period of longtail tuna during the present study clearly indicate that the fishes fed voraciously in the pre-spawning months for energy reserves needed for final maturation and spawning. The positive relationship of SFI with GSI in the remaining months could be due to increased presence of immature or maturing fishes in the catch, as longtail tuna breeds throughout the year with a major peak and few minor peaks of spawning (Yesaki, 1982; Cheunpan, 1984; Griffiths et al., 2007; Abdussamad et al., 2012).

\section{Acknowledgements}

The authors sincerely acknowledge the constant encouragement, support and valuable suggestions of Dr. G. Syda Rao, former Director ICAR-CMFRI and Dr A. Gopalakrishnan, Director, ICAR-CMFRI, Kochi. Acknowledgements are due to ICAR-CMFRI for the funding support.

\section{References}

Abdussamad, E. M., Said Koya, K. P., Shubhadeep Ghosh, Prathibha Rohit, Joshi, K. K., Manojkumar, B., Prakasan, D., Kemparaju, S., Elayath, M. N. K., Dhokia, H. K., Manju Sebastine and Bineesh K. K.. 2012. Fishery, biology and population characteristics of longtail tuna, Thunnus tonggol (Bleeker, 1851) caught along the Indian coast. Indian J. Fish., 59(2): 7-16.

Aidan Hunter, Douglas C. Speirs and Michael R. Heath 2015. Fishery-induced changes to age and length dependent maturation schedules of three demersal fish species in the Firth of Clyde. Fish. Res., 170: 14-23.

Al-Nahdi, A. Al-marzouqi, A.,Al-rasadi, E. and Groeneveld, J. C. 2009. The size composition, reproductive biology, age and growth of large head cutlass fish Trichiurus lepturus Linnaeus from the Arabian Sea coast of Oman. Indian J. Fish., 56(2): 73-79.

Bandpei, A., Mashhor, M. A. M., Abdolmaleki, S. H., Najafpour, S. H., Bani, A., Pourgholam, R., Fazli, H., Nasrolahzadeh, H. and Janbaz, A. A. 2011. The environmental effect on spawning time, length at maturity and fecundity of Kutum (Rutilus frisii kutum, Kamensky, 1901) in southern part of Caspian Sea, Iran. Iranica J. Ener. Environ., 2(4): 374-381.

Blaber, S. J. M. 2002. Fish in hot water: the challenges facing fish and fisheries research in tropical estuaries. J. Fish Biol., 61: $1-20$.

Bror Jonsson, Anders G. Finstad and Nina Jonsson 2012. Winter temperature and food quality affect age at maturity: An experimental test with Atlantic salmon (Salmo Salar). Canadian J. Fish. Aquatic Sci., 69(11): 1817-1826.

Cheunpan, A. 1984. Sexual maturity, size at maturity and spawning season of longtail tuna ( $T$. tonggol), eastern little tuna (E. affinis) and frigate mackerel (A. thazard) in the Gulf of Thailand. Fisheries Report of the Marine Fisheries Division of the Department of Fisheries, Bangkok, 43: 23 pp.

Chiang, W. C., Hsu, H. H., Fu, S. C., Chen, C. L., Chen, W. Y. and Cheng, D. C. W. S. 2011. Reproductive biology of longtail tuna (Thunnus tonggol) from coastal waters off Taiwan. IOTC-2011-WPNT01-30. Biological studies on tuna and tuna-like fishes in the west of the Gulf of Thailand and off east coast of Peninsular Malaysia. Fisheries Report of the Marine Fisheries Division of the Department of Fisheries, Bangkok, 4: $25 \mathrm{pp}$. 
Chiou, W., Chen, C., Wang, C. and Chen, C. 2006. Food and feeding habits of ribbonfish Trichiurus lepturus in coastal waters of south-western Taiwan. Fish. Sci., 72: 373-381.

Collette, B. B. and Nauen, C. E. 1983. FAO species catalogue. vol. 2. Scombrids of the world. An annotated and illustrated catalogue of tunas, mackerels, bonitos and related species known to date. FAO Fisheries Synopsis, 125: 137.

Dawood Al-Mamari, Lubna Al-Kharusi, Fatma Al-Kiyumi, Saeed Al-Shogebai, Ibrahim Al-Anboori, Rashed AlSeneadi and Sergiy Khrorv 2014. Record of the largest longtail tuna, Thunnus tonggol (Bleeker, 1851) from offshore Salalah in the Sultanate of Oman. J. Fish., 2 (3): 215-216

Faltas, S. N. 1993. Studies on purse-seine fisheries in the Egyptian Mediterranean waters with special reference to the biology of sardine in the catch. M. Sc. Thesis, Faculty of Science, Alexandria University.

Farley, J. H., Clear, N. P., Leroy, B., Davis, T. L. O. and McPherson, G. 2003. Age and growth of bigeye tuna (Thunnus obesus) from the eastern and western AFZ. Report No. 2000/100. CSIRO Marine Research, Tasmania, Australia, 93 pp.

Fonteneau, A. 2002. Estimated sex ratio of large yellowfin taken by purse seiners in the Indian Ocean; comparison with other oceans, IOTC Proceedings, p. 279-281.

Griffiths, S. P., Fry, G. C., Manson, F. J. and Pillans, R. D. 2007. Feeding dynamics, consumption rates and daily ration of longtail tuna (Thunnus tonggol) in Australian waters, with emphasis on the consumption of commercially important prawns. Mar. Freshw. Res., 58: 376-397.

Griffiths, S. P., Fry, G. F., Manson, F. J. and Lou, D. C. 2010. Age and growth of longtail tuna (Thunnus tonggol) in tropical and temperate waters of the central Indo-Pacific. ICES J. Mar. Sci., 67: 125-134.

Hedayatifard, M. 2007. The surveying of biological characteristics of long tail tuna (Thunnus tonggol) in the southern coasts of Iran. Proceedings of the International Conference on Science and Technology of Aquaculture, Fisheries and Oceanography in the Arabian Seas, 10-13 February 2007. State of Kuwait, p. 1-11.

Helser, T. E. and Almeida, F. P. 1997. Density-dependent growth and sexual maturity of silver hake in the north-east Atlantic. $J$. Fish. Biol., 51: 607-623.

IPTP 1992. Report on the workshop on stock assessment of yellowfin tuna in the Indian Ocean, 7-12 October 1991, Colombo, Sri Lanka, $90 \mathrm{pp}$.

Itoh, T., Yuki, Y. and Tsuji, S. 1999. Spawning possibility and growth of longtail tuna Thunnus tonggol, in the water around Japan. Bulletin of the National Research Institute of Far Seas Fisheries, 36: 47-53.

John, M. E. and Sudarshan, D. 1993. Fishery biology of yellowfin tuna occurring in oceanic fishing in Indian Seas. In: Sudarshan, D. and John, M. E. (Eds.), Tuna research in India, Fishery Survey of India, Bombay, India. p. 39-61.
Juanes, F. and Conover, D. O. 1994. Rapid growth, high feeding rates and early piscivory in young of the year blue fish (Pomatomus saltatrix). Can. J. Fish. Aquat. Sci., 51: 1752-1761.

June, F. C. 1953. Spawning of yellowfin tuna in Hawaiian waters. Fish. Bull., 54: 47-64.

Kaymaram, F., Darvishi, M. F., Parafkandeh, Sh. Ghasemi and Talebzadeh, S. A. 2011. Population dynamic parameters of Thunnus tonggol in the north of the Persian Gulf and Oman Sea. IOTC-2011WPNT01-18.

Khanna, S. S. and Singh, H. R. 2005. A textbook of fish biology and fisheries. Narendra Publishing House, Delhi, 170 pp.

Klinmuang, H. 1978. Preliminary studies on the biology of tunas in the west of the Gulf of Thailand and off the east coast of peninsular Malaysia. Fisheries Report of the Marine Fisheries Division of the Department of Fisheries, Bangkok, 5: 27.

Kume, S. and Joseph, J. 1969. Size composition and sexual maturity of Gill-fish caught by Japanese long line fishery in the Pacific Ocean east of 130 degrees W. Bull. Fr. Sears Fish. Res. Lab. No. 2.

Labropoulou, M.. Machias, A.. Tsimenides, N. and Eleftheriou, A. 1997. Feeding habits and ontogenetic diet shift of the striped red mullet, Mullus surmuletus Linnaeus, 1758. Fish. Res., 31: 257-267.

Martins, A. S., Haimovici, M. and Palacios, R. 2005. Diet and feeding of the cutlass fish Trichiurus lepturus in the subtropical convergence ecosystem of southern Brazil. J. Mar. Biol. Ass. U. K., 85: 1223-1229.

Nakamura, E. L. 1968. Visual acuity of two tunas, Katsuwonus pelamis and Euthynnus affinis. Copeia, 1: 41-49. doi:10.23 $07 / 1441548$.

Ogunola, O. S. and Palanisami, T. 2016. Microplastics in the marine environment: Current status, assessment methodologies, impacts and solutions. J. Pollut. Eff. Cont., 4:161. doi:10.41 72/2375-4397.1000161

Olson, R. J. and Boggs, H. 1986. Apex predation by yellowfin tuna (Thunnus albacares): independent estimates from gastric evacuation and stomach contents, bioenergetics and caesium concentrations. Can. J. Fish. Aquat. Sci., 43(9): 1760-1775.

Pillai, N. G. K. and Ganga, U. 1985. Fishery and biology of tunas in the Indian seas. Harvest and post-harvest technology of fish, Central Marine Fisheries Reserach Institute, Kochi, p. 10-35.

Pinkas, L., Oliphant, M. S. and Lverson, I. L. K. 1971. Food habits of albacore, bluefin tuna and bonito in California waters. Fish Bull., 152: 1-139.

Roger, C. 1994. Relationships among yellowfin and skipjack tuna, their prey fish and plankton in the tropical western Indian Ocean, Fish. Oceanogtr., 3: 133-141.

Rohit, P. and Rammohan, K. 2009. Fishery and biological aspects of yellowfin tuna Thunnus albacares along Andhra Coast, India, Asian Fish. Sci., 22: 235-244.

Schaefer, K. M. 1998. Reproductive biology of yellowfin tuna (Thunnus albacares) in the eastern Pacific Ocean. Inter-Amer. Trop. Tuna Comm. Bull., 21: 201-272. 
Serventy, D. L. 1942. Notes on the economics of the northerntuna (Kishinoella tonggol). J. Sci. Ind. Res. (India), 15: 94-100.

Serventy, D. L. 1956. Additional observations on the biology of the northern bluefin tuna, Kishinoella tonggol (Bleeker), in Australia. Aust. J. Mar. Fresh. Res., 7(1): 44-63.

Sheppard, C., Price, A. and Roberts, C. 1992. Marine ecology of the Arabian region. Academic Press, London, 347 pp.

Shinkafi, B. A. and Ipinjolu, J. K. 2012. Gonadosomatic index, fecundity and egg size of Auchenoglanis occidentalis (Cuvier and Valenciennes) in river Rima, North-western Nigeria. Nigerian J. Basic Appl. Sci., 20(3): 217-224.

Silas, E. G. 1967. Tuna fishery of the Tinnevelly coast, Gulf of Mannar. Symposium Series of the Marine Biological Association of India, 1: 1083-1118.

Sivadas, M. and Wesley, S. G. 2007. Feeding habits of skipjack tuna, Katsuwonus pelamis associated with flotsam in Minicoy, Lakshadweep. J. Ecobiol., 21(1): 57-62.

Sudarshan, D., Sivaprakasam, T. E., John, M. E., Bhargava, A. K., Patil, S. M. and Naik, V. V.1991. Chartered fishing vessels operations in the EEZ. Fishery Survey of India Publication No.1, $29 \mathrm{pp}$.

Wild, A., Wexler, J. B. and Foreman, T. J. 1995. Extended studies of increment deposition rates in otoliths of yellowfin and skipjack tunas. Bull. Mar. Sci., 57: 555-562.

Wilson, M. A. 1981. The biology, ecology and exploitation of longtail tuna, Thunnus tonggol (Bleeker) in Oceania Macquarie University, New South Wales, 195 pp.

Yesaki, M. 1982. Thailand biological and environmental observations. A report prepared for the pole-and-line tuna fishing in southern Thailand project. FAOFI: DP/THA/77/ 008: Field Doc., 3: 46

Yesaki, M. 1987. Synopsis of biological data on longtail tuna, Thunnus tonggol. Indo-Pacific Tuna Development and Management Programme, IPTP/87/WP/16, 56.

Yesaki, M. 1993. A review of the biology and fisheries for longtail tuna (Thunnus tonggol) in the Indo-Pacific region. FAO Fisheries Technical Paper, FAO, Rome, 439 pp.

Date of Receipt $\quad$ : 30.03 .2018

Date of Acceptance : 11.06 .2018 